\title{
Justice bubbles for the privileged: A critique of the Investor-State Dispute Settlement Proposals for the EU's Investment Agreements
}

\author{
Anil Yilmaz-Vastardis
}

There is the old idea, which has withstood the passage of time, that dominant social forces in society maintain their domination not through the use of force but through having their worldview accepted as natural by those over whom domination is exercised. ${ }^{1}$

\section{A. Introduction}

Historically, the use of international arbitration to resolve foreign investment disputes was advocated to prevent discrimination against foreign investors and avoid violation of their due process rights by so-called abusive governments with weak judiciaries. For this reason, the use of international investment arbitration (IIA), which arguably has the strongest rights enforcement mechanism existing in international law, ${ }^{2}$ has been perceived as facilitating access to justice for foreign investors at the international level. Despite IIA's popularity with investors, this system of dispute settlement has been criticised by state actors, legal scholars, and civil society activists alike. In response, the European Union (EU) has proposed establishing a permanent investment court system (ICS) which would settle investment disputes between EU member states and foreign investors. ${ }^{3}$ According to the EU, the ICS will remedy many of the observed flaws in the IIA model.

\footnotetext{
${ }^{1}$ B S Chimni 'Third World Approaches to International Law: A manifesto' 8 International Community Law Review (2006) 3, 15.

2 B A Simmons, 'Bargaining over BITS, Arbitrating Awards: The Regime for Protection and Promotion of International Investment', 66 World Politics (2014) 12, 17.

${ }^{3}$ Together with Canada, the EU is also promoting a multilateral version of the ICS: 'European Commission and Canadian Government co-host discussions on a multilateral investment court, Brussels 13 December 2016', available at http://europa.eu/rapid/press-release IP-16-4349 en.htm (last visited 10 February 2018). China is also reported to have plans to establish a court system to settle trade and investment disputes with foreign investors: 'China's plans for creating new international courts are raising fears of bias CNBC, Nyshka Chandran 1 February 2018', https://www.cnbc.com/2018/02/01/china-to-create-international-courts-for-belt-and-roaddisputes.html (last visited 4 February 2018).
} 
While some of its shortcomings may be resolved, this essay questions the appropriateness of promoting special routes for access to justice (understood in a broad sense to encompass its various possible forms) for a class of privileged investors. It highlights the potentially detrimental effects of such a promotion on local justice mechanisms that serve the whole of society. It argues that judicialising investor state dispute settlement (ISDS) in the direction envisaged by the EU's ICS is the wrong approach because it prioritises institutions of justice for foreign investors over the improvement of local institutions that could provide justice for members across society, including foreign investors. Throughout this essay, the prioritisation of remediating foreign investor grievances via ISDS is referred to as a 'justice bubble'.

Two caveats are in order. First, the creation of the ICS and improvements to local institutions of justice are not necessarily competing agendas amounting to a zero sum game. States could properly resource both the improvement of local institutions and special modes of dispute settlement for foreign investors. That said, if local institutions of justice are strong, the question arises as to why states would need to promote special modes of dispute settlement serving only foreign investors. After all, substantial resources are needed to set up and maintain an investment court system. Where states prioritise allocating resources into the creation and maintenance of justice bubbles for the privileged, they are inevitably taking away valuable resources and attention which could have been used, had the political will existed, to improve the effectiveness of local judicial and non-judicial protection mechanisms that serve all members of society.

The second caveat is to make it clear that the objection raised in this essay is not to the ad hoc use of international arbitration in settling investor-state disputes-rather it is to the efforts to validate the idea that IIA should be the default and most appropriate mode of resolving investor-state disputes. While the critique presented here is relevant beyond the EU's agreements, the latter deserve particular attention since their adoption would in all likelihood entrench ever greater prioritisation-on a global scale-of the commercial interests of the wealthiest few over wider societal interests by, inter alia, making justice bubbles for investors more permanent. Introducting a standing court system is likely to lock a relatively large number of states into this mode of dispute settlement for decades, and potentially define the new ISDS system as a template of good governance. 
In 2017 the Court of Justice of the Europan Union (CJEU) issued an opinion clarifying that the EU and its members states share competence on the question of ISDS and that member state approval is therefore required for the adoption of the ICS. ${ }^{4}$ The fact that the EU and its member states are currently at a critical junction in terms of the path to choose for ISDS in the EU's new investment treaty program makes this essay particularly timely. I begin by critically analysing the imposition of IIA as the most appropriate method for resolving investor-state disputes. A brief overview of the recent and increasing backlash against IIA follows. The responses this attracted in the form of a ICS proposal by the EU are then examined. The final section argues that the establishment of a permanent investment court is a short-sighted solution to shortcomings in local access to justice which is likely to undermine domestic legal developments. What is needed is a rejection of the outsourcing of the settlement of investment disputes on a permanent basis. If this were achieved, it would constitute a paradigmatic shift in approaches to access to justice.

\section{B. The imposition of IIA as the most appropriate ISDS method}

Investor-state disputes can be resolved in various fora. As a generic phrase, ISDS can encompass judicial proceedings, conciliation, mediation, negotiation and arbitration. ${ }^{5}$ IIA has long been the most popular method to resolve foreign investment disputes for wellresourced investors. Investors able to mount claims against host states through the IIA mechanism are typically wealthy, given the huge associated costs. Small businesses are less likely to have the necessary funds to be able to resort to this mechanism. An OECD survey showed that 'costs for the parties in recent ISDS cases have averaged over USD 8 million with costs exceeding USD 30 million in some cases.' ${ }^{6}$ In this essay, references to 'privileged investors' are to those investors who can afford this very special mode of dispute resolution.

\footnotetext{
${ }^{4}$ Opinion 2/15 of the Court of Justice of the European Union, 16 May 2017.

${ }^{5}$ Investment disputes may also be brought before the courts of the regional human rights systems; see Velikovi v Bulgaria ECHR App No 43278/98, 48 EHRR 27 (2007).

${ }^{6}$ OECD, 'Investor-state dispute settlement public consultation: 16 May-9 July 2012' available at http://www.oecd.org/daf/inv/internationalinvestmentagreements/50291642.pdf (last visited 10 February 2018).
} 
The procedural empowerment of investors via IIA has been described as the 'most effective means of resolving investor-state disputes"7 $-a$ 'real innovation' 8 in international investment law (IIL). Most investment treaties neither require exhaustion of local remedies nor do they provide extensive grounds for reviewing IIA awards. Moreover, they institute a monopoly over the interpretation of the bilateral investment treaty ('BIT') provisions, which are typically 'relatively brief and [written] at a fairly high level of generality'. ${ }^{9}$ Because of this, IIA rulings cannot but impact the practice of states regarding their IIL obligations ${ }^{10}$ as well as having an influence on states' non-investment obligations, such as those under international human rights law or environmental law. ${ }^{11}$

An investment treaty is not the only place where arbitration is used. International and local commercial disputes, as well as inter-state disputes, are also frequently resolved through arbitration. This can be a legitimate method for resolving disputes, founded on the principles of consent and party autonomy. ${ }^{12}$ In most cases, private parties mutually agree, in a contract, to submit their disputes to arbitration rather than resorting to national courts. They do so for a variety of reasons, for example concerns for confidentiality or trust in the arbitrators' expertise. In these instances, the decision to submit to arbitration is made ad hoc; the parties do not submit all future disputes between themselves to arbitration, but only those that relate to the specific legal relationship referred to in the arbitration agreement. With the reach and impact of the agreement strictly limited to the contract and its signatories, arbitration normally does not constitute a large-scale transfer of judicial authority.

In contrast, investment treaty arbitration's personal and material reach is so wide that it entails such a transfer. The source of most contemporary investment arbitration,

\footnotetext{
${ }^{7}$ C Reiner and C Schreuer, 'Human Rights and International Investment Arbitration', in P M Dupuy, E U Petersmann and F Francioni (eds.), Human Rights in International Investment Law and Arbitration (Oxford UP 2009), 82.

${ }^{8}$ S Franck, 'Foreign Direct Investment, Investment Treaty Arbitration and the Rule of Law' 19 McGeorge Global Business and Development Law Journal (2007) 337, 343.

${ }^{9}$ S Ratner, The Thin Justice of International Law (Oxford UP, 2015) 350 and 371.

10 Ibid 371.

${ }^{11}$ C Titi, The Right to Regulate in International Investment Law (Nomos/Hart 2014).

12 N Blackaby, C Partasides, A Redfern \& M Hunter, Redfern and Hunter on International Arbitration $6^{\text {th }}$ Ed. (Oxford UP 2015) 71.
} 
investment treaties negotiated between states see a state making a standing offer to arbitrate to an indeterminate number of investors from the other state party. This offer can be accepted by any qualifying investor through the initiation of arbitral proceedings. The host state may not even be aware of the existence of a dispute until it receives the notice of arbitration. The privileged investor which resorts to this mechanism does not need to have negotiated an arbitration agreement for a defined legal relationship. Instead, it can just claim the 'right to arbitrate' which its state has negotiated for its benefit and that of other qualifying investors. This has now become the normal way of settling disputes between international investors and host states. The EU's proposals would render permanent the large-scale transfer of judicial authority this entails.

Two arguments are often advanced to justify the use of IIA as the most appropriate method of ISDS. The first is that it improves access to justice for foreign investors, ${ }^{13}$ the second that it contributes to the development of the rule of law through the application of agreed minimal standards in host states ${ }^{14}$ as well as internationally. ${ }^{15}$ These two arguments are clearly related given that access to justice is a vital component of the rule of law. While the first justification is narrower in scope, the second one is a broader and bolder assumption. Neither stands.

The use of arbitration to resolve foreign investment disputes was advocated in the postcolonial era to prevent discrimination against foreign investors and avoid denial of justice, leading to a diminution of investment value, ${ }^{16}$ by governments which it was feared would be abusive and/or would only have weak judiciaries. ${ }^{17}$ Distrust of the local judiciary as

\footnotetext{
${ }^{13}$ F Francioni, 'Access to Justice, Denial of Justice and International Investment Law', 20 European Journal of International Law (2009) 729.

${ }^{14}$ S Franck (2007); B K Guthrie, 'Beyond Investment Protection: An Examination of the Potential Influence of Investment Treaties on Domestic Rule of Law' 45 NYU Journal of International Law and Politics (2013), 1151; J Paulsson, 'Enclaves of Justice' University of Miami Legal Studies Research Paper No.2010-29, available at http://ssrn.com/abstract=1707504 (last visited 10 February 2018).

${ }^{15}$ B Kingsbury and S Schill, 'Investor-State Arbitration as Governance: Fair and Equitable Treatment, Proportionality and the Emerging Global Administrative Law' (2009). New York University Public Law and Legal Theory Working Papers. 146 available at http://Isr.nellco.org/nyu plltwp/146 (last visited 10 February 2018) ${ }^{16} \mathrm{D}$ Schneiderman, 'Investing in Democracy? Political Process and International Investment Law' 60 University of Toronto Law Journal (2010) 909, 911.

${ }^{17}$ M-B Dembour and N Stammers, 'Free trade, protectionism, neolibearlism: Tensions and continuities', this volume; G Van Harten, 'Five Justifications for Investment Treaties: A Critical Discussion' 2(2) Trade Law and
} 
corrupt or biased against foreign investors was perceived as a factor which could have deterred investors from entering the host state market. The solution found was to internationalise the resolution of foreign investment disputes. Amid worries that protectionist policies of host states would harm the liberalisation of global investment, it was argued that international rules and dispute settlement would help depoliticise disputes. ${ }^{18}$ With its declared aim of empowering foreign investors to access justice, IIA soon became presented as a necessity for any state wishing to attract foreign investment. The idea was quickly accepted that the substantive rights of investors anywhere in the world need to be backed up by procedural means capable of enforcing those rights.

Mainstream thinking on IIA accepts that releasing foreign investors from the necessity of exhausting domestic remedies prior to initiating international arbitration is in place in order to prevent discrimination against, and give voice to, foreign investors who are unrepresented in the host state's political process. ${ }^{19}$ This has the effect of prioritising international solutions which, in turn, reinforces the common perception that domestic institutions, actors, and cultures undermine democracy and human rights, whilst international law promotes them. ${ }^{20}$ The view of IIA as the impartial guardian of foreign investor's rights epitomises the sanctity of the international and the distrust of the local. Interestingly, it also serves to underpin the argument that IIA stands to improve host states' poor records in terms of the rule of law. What the rule of law means is admittedly elusive. ${ }^{21}$ However, in IIL debates, it tends to refer to democratic governance, limitation of

Development (2010) 19, 33; J Alvarez, The Public International Law Regime Governing International Investment, (Martinus Nijhoff Publishers, 2011) 113.

${ }^{18} \mathrm{~N}$ Tzouvala, 'Ordo-liberal Origins of Modern International Investment Law: Constructing Competition on a Global Scale' (Forthcoming in European Yearbook of International Economic Law) on file with the author. ${ }^{19}$ Hence the link made between access to justice and the 'minimum standard of treatment of aliens': see Francioni (2009), 731. See also Técnicas Medioambientales Tecmed, S.A. v. The United Mexican States (Tecmed $\checkmark$ Mexico), ICSID Case No. ARB (AF)/00/2 para 122.

${ }^{20}$ A Orford, 'Locating the International: Military and Monetary Interventions after the Cold War', 38(2) Harvard International Law Journal (1997) 444, 484 ('the international as a level of governance is the site of both emancipatory and oppressive values and projects, and that threats to democracy and human rights exist at the international level as well as the local level'.) See also See also M-B Dembour and T Kelly, 'Introduction: The Social Lives of International Justice', in M-B Dembour and T Kelly, Paths to International Justice: Social and Legal Perspectives (Oxford UP 2007) 1-28, 13.

${ }^{21}$ As Tamanaha has observed, the rule of law 'stands in the peculiar state of being the preeminent legitimating political ideal in the world today, without agreement upon precisely what it means': B Z Tamanaha, On the Rule of Law: History, Politics, Theory (Cambridge UP, 2004) 4. 
government authority by law, legal certainty, protection of basic rights and, most importantly in the context of this essay, access to justice.

An argument often made by proponents of investment liberalisation is that compelling host states to comply with international investment standards through recourse to an external enforcement mechanism has a positive effect on the local rule of law in the host state. ${ }^{22}$ It is argued that this happens in two ways. First decisions of IIA tribunals compels host states to comply with an external and a more just standard of treatment. ${ }^{23}$ Second, by leaving the final word to impartial and independent IIA tribunals, an increase in the levels of investment protection and legal certainty is achieved, in turn leading to economic and social development in the host state with positive effects on the rule of law in that state. Thus, for ardent proponents of the rule of law function such as Kingsbury and Schill, IIA is a tool capable of fostering 'democratic accountability and participation ..., good and orderly state administration and the protection of rights and other deserving interests' ${ }^{24}$ In a similar vein, Franck presents investment treaty arbitration as a contributing factor to the development of the rule of law in host states with a weak rule of law. She argues that 'investment treaty arbitration may create incentives for foreign investment by fostering the development of the rule of law'.25

In fact, studies which have attempted to calculate the impact of IIL commitments on the volume of inward investment are inconclusive, ${ }^{26}$ as are those which have tried to examine the impact on the local rule of law. Although IIA commitments are sometimes acknowledged not to be a panacea for remedying a deficient rule of law, ${ }^{27}$ what needs to be

\footnotetext{
${ }^{22}$ Franck (2007).

${ }^{23}$ Ibid 367.

${ }^{24}$ Kingsbury and Schill (2009), 8.

${ }^{25}$ Franck (2007), 340.

${ }^{26}$ L Poulsen, Bounded Rationality and Economic Diplomacy: The Politics of Investment Treaties in Developing Countries (Cambridge UP, 2015) 7-8.

${ }^{27} \mathrm{R}$ Dolzer, 'The Impact of International Investment Treaties on Domestic Administrative Law' 37 International Law and Politics (2006), 952.
} 
challenged is the very idea that procedural guarantees contained in IIL make a positive contribution to improving deficiencies in the domestic rule of law. ${ }^{28}$

Tzouvala views IIL and its enforcement via IIA as a model of governance that is inherently anti-democratic. She argues that IIL should 'be understood as a means for safeguarding hierarchy and power within each and every state ... dictat[ing] acceptable models for state organisation and economic intervention and that is fundamentally inimical to mass politics and/or democratic determination of economic policies' ${ }^{29}$ Schneiderman warns against the creation of legal enclaves for foreign investors on the grounds that this might deprive the investor voice from the enterprise of creating good and generalised rule of law institutions in the host country'. ${ }^{30}$ A recent empirical study on the functions of IIA which explores the relationship of IIA with the rule of law found that IIA 'creates at best a weak rule of law effect in countries with a poor record of respect for the rule of law'. ${ }^{31}$ These conclusions should prompt us to seriously question the proposition that IIA produces positive rule of law effects in host states.

\section{The EU's response to the backlash against IIA}

There has been an intense backlash against IIA from various actors, including states, civil society and scholars. Critiques of the current system vary from arguing for outright

\footnotetext{
${ }^{28}$ Schultz and Dupont (2015). Even in states with more robust rule of law increased use of arbitration might hamper the consistent development of the law by courts. The Lord Chief Justice of England and Wales has argued that the development of the common law by courts in England and Wales was hampered in areas of law where arbitration is increasingly used, available at https://www.judiciary.gov.uk/wpcontent/uploads/2016/03/lcj-speech-bailli-lecture-20160309.pdf (last visited 10 February 2018)

${ }^{29}$ Tzouvala, 'The Ordo-Liberals Origins of Modern International Investment Law: Constructing Competition on a Global Scale', in A Rasulov and J D Haskell (eds) European Yearbook of International Economic Law (Springer, forthc).

30 Schneiderman (2010), 937.

${ }^{31}$ T Schultz and C Dupont, 'Investment Arbitration: Promoting the Rule of Law of Over-empowering Investors? A Quantitative Empirical Study' 25(4) European Journal of International Law (2015) 1147, 1163.
} 
rejection ${ }^{32}$ to offering suggestions for remedying its flawed features. ${ }^{33}$ Critics particularly refer to the proceedings' lack of transparency and inclusiveness; the high fees charged by arbitrators and legal representatives; the absence of an appeals process; and the inconsistency of decisions on issues involving public interest. They also question the impartiality of arbitrators by pointing to concerns over general conflicts of interest, elitism, and specific vested financial interests in certain outcomes. At a more substantive level, the way IIA serves to advance neoliberal policies around the globe, in particular imposing such policies on developing states, has been denounced. ${ }^{34}$

The potentially detrimental effect of IIA on democratic governance merits particular consideration. It has been convincingly argued that broad and inconsistent interpretations by IIA tribunals of the substantive rights afforded to investors under the IIL regime have a shrinking effect on the policy space of elected governments. ${ }^{35}$ Indeed, host states have not always been successful in defending their actions even when explaining they had to interfere with investments in order to fulfil their human rights obligations under international law and domestic constitutions. ${ }^{36}$ Particular features of IIA also prompt suspicions of a built-in bias in favour of investors, for example the facts that the process can only be initiated by investors under BITs and that investors are endowed with substantive rights but without incurring reciprocal obligations.

Solutions offered to rectify these defects have included: enhancing transparency of proceedings and arbitral decisions; increasing third party participation in the procedure via

\footnotetext{
32 D Schneiderman (2010); OHCHR, Investor-State dispute settlement undermines rule of law and democracy, UN expert tells Council of Europe, 19 April 2016, available at: http://www.ohchr.org/EN/NewsEvents/Pages/DisplayNews.aspx?NewsID=19839\&LangID=E (last visited 10 February 2018).

${ }^{33}$ See for instance, G Van Harten, Sovereign Choices and Sovereign Constraints: Judicial Restraint in Investment Treaty Arbitration (Oxford UP, 2013); S Schill, 'Enhancing International Investment Law's Legitimacy: Conceptual and Methodological Foundations of a New Public Law Approach', 52 Vanderbilt Journal of International Law (2011) 57.

${ }^{34}$ M Sornarajah, 'Toward Normlessness: The Ravage and Retreat of Neo-Liberalism in International Investment Law' 2 Yearbook of International Investment Law and Policy (2010) 595. D Schneiderman, Resisting Economic Globalization: Critical Theory and International Investment Law (Palgrave Macmillan 2013).

${ }^{35}$ Schneiderman (2010); Van Harten (2013).

${ }^{36}$ Tecmed v Mexico; Suez, Sociedad General de Aguas de Barcelona, S.A.and Vivendi Universal, S.A. v. Argentine Republic, ICSID Case No. ARB/03/19; Urbaser S.A. and Consorcio de Aguas Bilbao Bizkaia, Bilbao Biskaia Ur Partzuergoa $v$ The Argentine Republic, (Award, 8 December 2016) ICSID Case No. ARB/07/26.
} 
amicus curiae interventions; setting up an appeals mechanism; introducing codes of conduct for arbitrators; and limiting the interpretive radius of substantive protections in treaty provisions by listing legitimate policy grounds that can be invoked by host states. Most importantly, in September 2015, the EU proposed the creation of an Investment Court System, 'to replace the old ISDS model in all [EU]'s ongoing and future trade negotiations'. ${ }^{37}$ This was in response to the negative reactions from around Europe against the initial plans to incorporate IIA into TTIP. The proposal immediately became the flagship innovation of the EU's infant investment policy. ICS has been incorporated into CETA, and it is also now found in the EU-Vietnam free trade agreement as the investment tribunal system. ${ }^{38}$ The EU's Trade Commissioner has presented the proposal as revolutionary, claiming it expresses the EU's aspiration to lead the way globally in reforming the current IIA model. ${ }^{39}$

The ICS proposal offers a reformed version of the current IIA system, attempting to address the concerns raised. In the words of the CETA negotiators, the proposed rules aim to institutionalise a fairer and more transparent version of IIA. ${ }^{40}$ The key innovation of the ICS is the establishment of a permanent arbitration mechanism consisting of a first instance tribunal and an appeals tribunal operating under full transparency. ${ }^{41}$ With this, the EU aims to achieve consistency and transparency in decision-making; overcome the ethical challenges to arbitrator appointments and conduct; $; 2$ and increase third party participation in the proceedings. ${ }^{43}$ Other notable provisions of the proposal include sections on interpretation, ${ }^{44}$ on restricting parallel claims and claims by investors who acquired the

\footnotetext{
${ }^{37}$ C Malmström, Proposing an Investment Court System, 16 September 2015, available at https://ec.europa.eu/commission/2014-2019/malmstrom/blog/proposing-investment-court-system en (last visited 10 February 2018).

${ }^{38}$ Free Trade Agreement Between the European Union and the Socialist Republic of Vietnam, Chapter II Article 12.

39 Malmström (2015).

40 Joint statement by C Malmström and C Freeland on Canada-EU Comprehensive Economic and Trade Agreement (CETA), 29 February 2016, available at http://europa.eu/rapid/press-release STATEMENT-16446 en.htm (last visited 10 February 2018).

${ }^{41}$ See Articles 9, 10 and 18 of the ICS proposal text for TTIP, available at http://trade.ec.europa.eu/doclib/docs/2015/september/tradoc 153807.pdf (last visited 10 February 2018).

42 Ibid, Article 11.

43 Ibid Articles 22 and 23.

${ }^{44}$ Ibid Article 13(5).
} 
investment for purposes of submitting a dispute against the host state ${ }^{45}$ and on limiting mass claims by an unidentified number of claimants. ${ }^{46}$

To justify the adoption of ICS, the Commission refers to the potential lack of impartiality of domestic courts in claims against host states, state immunity from suit, unavailability of certain remedies in domestic courts, and-most unconvincingly-to 'different applicable rules which cannot be invoked before domestic courts' ${ }^{47}$ The document does not clarify what exactly the obstacle would be for domestic courts to apply international treaty protections to cases before them, where these rules govern the substance of the dispute. ${ }^{48}$ There is ample evidence showing application of a wide variety of international law norms by domestic courts ranging from treaties on human rights to environmental protection. ${ }^{49}$

The Commission's proposal received mixed reactions from critical commentators. These can be divided into four main groups. The first group consists of those objecting to the adoption of international dispute settlement for investment disputes between liberal constitutional democracies on grounds that the negotiating parties have some of the most developed legal systems. ${ }^{50}$ For this group, IIA or ICS only makes sense for agreements with countries that do not provide adequate domestic legal protection. Weiler has labelled this double standard approach 'European hypocrisy' (in comments that predate the Commission's ICS proposal). ${ }^{51}$ In an approach representative of the second group, he wants to see IIA's most egregious defects corrected so that the system can then be transformed into a more permanent mechanism for all international investment disputes. At the same time there is recognition

\footnotetext{
45 Ibid Articles 14 and 15.

46 Ibid Article 6(5)

${ }^{47}$ Public consultation on modalities for investment protection and ISDS in TTIP, available at http://trade.ec.europa.eu/doclib/docs/2014/march/tradoc 152280.pdf (last visited 10 February 2018).

${ }^{48}$ The direct applicability of such rules will depend on the constitutional tradition of each contracting state. Even in states that follow a dualist model, treaty protections can be transposed into the domestic legal order via legislation.

${ }^{49}$ D Shelton, 'Normative Evolution in Corporate Liability for Violations of Human Rights and Humanitarian Law' 15 Austrian Review of International and European Law (2010) 45, 48-51

${ }^{50}$ See eg E U Petersmann 'Transformative Transatlantic Free Trade Agreements without Rights and Remedies of Citisens?' 18 Journal of International Economic Law (2015) 579, 600; M Kumm, An Empire of Capital? Transatlantic Investment Protection as the Institutionalisation of Unjustified Privilege, 25 May 2015, 4(3) ESIL Reflections

51 J Weiler, European Hypocrisy: TTIP and ISDS, 21 January 2015, EJIL:Talk! available at http://www.ejiltalk.org/european-hypocrisy-ttip-and-isds/ (last visited 10 February 2018).
} 
that there is still some way to go to achieve a good model of ISDS. ${ }^{52}$ The third group of reactions views the proposal as making only very limited improvements to IIA, and ICS 'mainly a re-branding exercise for ISDS'. ${ }^{53}$ This group calls for the creation of a more robust international court the jurisdiction of which would be conditioned on the exhaustion of domestic remedies. ${ }^{54}$ For the final group, whatever improvements the ICS proposal brings to the existing model, foreign investors will still be unjustifiably advantaged compared both to national businesses and the rest of members of a society. These critics argue that ICS should be abandoned, as does this essay..$^{55}$

\section{Why the justice bubble should not be reinforced}

What justifies treating privileged investors as a category of claimants who should be insulated from the access to justice mechanisms which exist at local, including national, level? Why should they be entitled to a purportedly more robust method of dispute settlement than any other member of society? I argue there is no good reason for this. The special treatment international investment disputes receives is unwarranted and, for the EU to reinforce it, is a move in the wrong direction. The second reason why this move should be resisted is that it creates an even more solid justice bubble and it is in the very nature of justice bubbles to undermine development.

\footnotetext{
52 See e.g. C Titi, 'The European Union's Proposal for an International Investment Court: Significance, Innovations and Challenges Ahead', Transnational Dispute Management (2017) 1; R Quick, 'Why TTIP Should Have an Investment Chapter Including ISDS', 49(2) Journal of World Trade (2015), 199; R Howse, 'Counting the Critics of Investor-State Dispute Settlement: the EU proposal for a judicial system for investment disputes' available at https://cdn-media.web-view.net/i/fij3t288ah/Courting the Criticsdraft1.pdf (last visited 10 February 2018); B Choudry, 2015: The Year of Reorienting International Investment Law', ASIL Insights, available at https://www.asil.org/insights/volume/20/issue/3/2015-year-reorienting-international-investmentlaw (last visited 10 February 2018); Schill, ASIL Insight https://www.asil.org/insights/volume/20/issue/9/european-commissions-proposal-investment-court-systemttip-stepping (last visited 10 February 2018).

${ }^{53} \mathrm{G}$ Van Harten, 'Key Flaws in the European Commission's Proposals for Foreign Investor Protection in TTIP', 12 Osgoode Legal Studies Research Paper No.16 (2016).

${ }^{54}$ See for instance, G Van Harten, Sovereign Choices and Sovereign Constraints: Judicial Restraint in Investment Treaty Arbitration (Oxford UP, 2013); S Schill, 'Enhancing International Investment Law's Legitimacy: Conceptual and Methodological Foundations of a New Public Law Approach', 52 Vanderbilt Journal of International Law (2011) 57.

${ }^{55}$ D Schneiderman (2010); OHCHR, Investor-State dispute settlement undermines rule of law and democracy, UN expert tells Council of Europe, 19 April 2016, available at: http://www.ohchr.org/EN/NewsEvents/Pages/DisplayNews.aspx?NewsID=19839\&LangID=E (last visited 10 February 2018).
} 
As said previously, there are thousands of investment treaties which contain substantive and procedural provisions that constitute an unprecedented international legal protection regime. This regime is designed to maximise investor protection and to minimise direct and indirect government interference with the returns on the investment. For investors, its obvious advantage is that it gives them the possibility of having their disputes with host states regarding their investment settled via mandatory international arbitration. IIA tribunals are often formed of highly qualified specialists. Problematically, their mandate is limited to applying the relevant investment treaty and, typically, the latter stipulates the rights of investors at a high level of abstraction. Inevitably, the succint and abstract formulation of substantive protections, coupled with the absence of a rule of binding precedent and the lack of an appeals mechanism, gives IIA tribunals considerable interpretative discretion.

Approaching the investor-state relationship and the disputes from a privity lens, one observes that IIL tends to take a narrow view of the nature and impact of the dispute. However, the way a dispute-concerning, for example, a water concession or the construction of a pipeline-is resolved can have serious effects beyond the immediate parties to the dispute, the more so since an IIA tribunal might hesitate to take public impacts into consideration given its mandate is limited by the investment treaty to deal only with investment interests. ${ }^{56}$ Since the objective of investment treaties is to promote and protect investments, tribunals generally interpret the abstract rules in a manner compatible with those objectives.

The Yukos dispute, which involved a series of claims against Russia by Yukos investors seeking compensation for the violation of their property and due process rights, can serve to illustrate the extent of the protections under the current IIA model. One set of proceedings took place before the European Court of Human Rights (ECtHR), ${ }^{57}$ a second set

\footnotetext{
${ }^{56}$ W M Reisman, 'Case Specific Mandates' versus 'Systemic Implications': How Should Investment Tribunals Decide? The Freshfields Arbitration Lecture, 29(2) Arbitration International (2013) 131.

${ }^{57}$ Case of Oao Neftyanaya Kompaniya Yukos v. Russia (Application no. 14902/04).
} 
before an IIA tribunal. The ECtHR ordered Russia to pay the claimants $€ 1.87$ billion in just satisfaction under the European Convention on Human Rights. This was the largest compensation this court had ever awarded. Still, it was dwarfed by the $\$ 50$ billion awarded by the IIA tribunal for essentially the same dispute under the Energy Charter Treaty. ${ }^{58}$

From the perspective of investors, the only obvious disadvantage of IIA as opposed to using domestic courts is the costs of using this procedure. In the Yukos case, the costs awarded to the claimant in the IIA proceedings reached up to $\$ 60$ million, while the ECtHR awarded $€ 300,000$ in costs - again an unprecedented amount for the ECtHR. Nonetheless, the high costs of using and maintaining IIA actually adds to its privileged nature since they limit its use to the few privileged investors who can afford it.

What makes the IIA system a justice bubble is not whether the outcomes of these cases tend to favour investors. ${ }^{59}$ Rather, the problem is that the cards are stacked in favour of the investors by design. In other words, a special forum is made de facto available only to wealthier investors to secure investment interests beyond the fora and remedies available to the other members of society in domestic legal systems.

If the underlying assumption is that investor-state disputes are most effectively settled internationally, then the ICS proposal can appear to be a genuine attempt to respond to some of the weakenesses identified by the backlash against IIA. If, however, domestic judiciaries respecting the rule of law are the gold standard for access to justice, why is the EU pushing for the ICS? If IIA or ICS are solutions to a genuine concern about defects in

\footnotetext{
${ }^{58}$ Yukos Universal Limited (Isle of Man) v. The Russian Federation, UNCITRAL, PCA Case No. AA 227; Later, the IIA award was set aside by domestic courts at the seat of arbitration (The Hague), on grounds that the IIA tribunal did not have jurisdiction. An English translation of the judgment available at http://www.italaw.com/sites/default/files/case-documents/italaw7258.pdf (last visited 10 February 2018). The Yukos claimants may still be able to enforce the IIA award, despite The Hague court's decision; See http://kluwerarbitrationblog.com/2016/05/13/the-us50-billion-yukos-award-overturned-enforcementbecomes-a-game-of-russian-roulette/ (last visited 10 February 2018 ).

59 The data available on outcomes has been interpreted in different ways by scholars; See for instance T Schultz and C Dupont (2015),15-16-17; S Franck, 'Development and Outcomes of Investment Treaty Arbitration', 50 Harvard International Law Journal (2009) 435; G Van Harten, 'The Use of Quantitative Methods to Examine Possible Bias in Investment Arbitration, Yearbook on International Investment Law and Policy 20102011 (Oxford UP 2010).
} 
domestic access to justice and rule of law, one would wish the EU to remedy the shortcomings in the local remedy systems. Especially given that the EU sees itself as a standard-setter which can positively influence the rest of the world, ${ }^{60}$ it should work at minimising the use of an international dispute settlement mechanism—not institutionalising a justice bubble for the few.

The premise of the argument for transferring settlement of investor-state disputes to international tribunals or courts is that international dispute settlement promises more effective legal protection for foreign investors. It is claimed that foreign investors could be at a disadvantage if they have to challenge host state acts in host state courts due to possible bias and discrimination against them on the basis of their nationality. ${ }^{61}$ In response to this alleged problem, policy-makers have taken the necessary steps to secure due process rights of investors as a matter of priority, in order to help investment flow without undue burden. However, even if it could be assumed that domestic courts and judges are indeed biased against foreign investors, the observation has to be made that investors do not form the only group against which domestic courts might carry biases. So, the question arises, what makes IIL disputes more important than other kinds of disputes, such that the creation of such a special and powerful dispute settlement mechanism is warranted for them alone? Would all disputes not deserve to be settled by impartial and efficient courts?

The adoption of the ICS model in CETA or TTIP leads one to ask whether the EU, its member states, Canada and the US fail to grant effective judicial protection to investors. The standard answer is no. In the EU, access to effective judicial protection is guaranteed for everyone, regardless of the nationality of the parties, in member state constitutions, under the ECHR, and in the EU Charter of Fundamental Rights. In the US and Canada due process rights are guaranteed by the respective constitutions of those countries. In all three jurisdictions, the abstract rights guaranteed in these core documents are brought to life by relatively strong national judiciaries. In the EU, a further level of protection is provided at

\footnotetext{
${ }^{60}$ The EU sees itself as a global leader in this field, viewing TTIP and CETA as potentially becoming the 'golden standard' of investment treaty-making, available at https://ec.europa.eu/commission/commissioners/20142019/malmstrom/blog/proposing-investment-court-system en (last visited 10 February 2018)

${ }^{61}$ Francioni (2009).
} 
the regional level also through the ECtHR and the CJEU. The right to a fair trial and access to remedy are among the few human rights granted to corporations, including corporate investors, on a par with individuals (as the Yukos case illustrates). Given this, attempts to justify the inclusion of IIA or ICS for these mega-regional agreements by reference to access to justice and rule of law arguments ring hollow. This observation is not meant to repeat Weiler's 'European hypocrisy' argument against IIA. Rather, what I wish to stress is the double standard promoted by policy-makers who prioritise safeguarding investor interests, while neglecting the effects of potential domestic rule of law flaws on the rest of the society, particularly the most disadvantaged groups.

Concerns about access to effective remedies in developed jurisdictions are not unjustified. There is, however, no evidence to suggest that European states, the US or Canada fail to provide effective remedies to investors. Rather, flaws in access to justice primarily affect members of low-income and vulnerable groups in these jurisdictions, ${ }^{62}$ and these 'groups most in need of legal assistance have the least access to political leverage that could secure it' ${ }^{63}$ Proponents of IIA often consider foreign investors vulnerable because they do not have the right to vote to elect representatives who will determine the policies affecting their investment. ${ }^{64}$ Yet the type of investor likely to use the IIA or ICS mechanisms has far more political leverage to secure its interests within the domestic legal system than many other portions of the society, particularly the poorest and most vulnerable. ${ }^{65}$ It is, at best, questionable to reduce democratic representation and political leverage to the act of voting and then to conclude that the ability to vote guarantees that the laws enacted by the legislature will equally guard the interests of all voters. Moreover, not having the ability to vote does not mean that one's interests will not be protected by legislation. Legal persons such as companies cannot participate in the democratic process through voting, but they can have very strong influence, via lobbying, to promote legislation that safeguards their

\footnotetext{
${ }^{62}$ The term 'vulnerable groups' are used to include, but not limited to, indigenous peoples, minority groups, single parents, homeless people, children, migrants and refugees, disabled.

${ }^{63}$ D L Rhode, Access to Justice (Oxford UP 2004), 3.

${ }^{64}$ Tecmed v Mexico; C Schreuer, 'Do We Need Investment Arbitration?', in J E Kalicki and A Joubin-Bret (eds) reshaping the Investor-State Dispute Settlement System: Journeys for the 21 $1^{\text {st }}$ Century (Brill Nijhoff 2015).

${ }^{65}$ Schneiderman (2013), 131.
} 
interests. ${ }^{66}$ At domestic and international governance levels, large corporate actors and business interests get their agenda pushed forward much more forcefully than civil society. ${ }^{67}$

There is no evidence to show that foreign investors are more vulnerable to negative bias in domestic courts than any other group. Even relative to the treatment of domestic investors, foreign investors are not necessarily more vulnerable to political risk than their domestic counterparts. ${ }^{68}$ Indeed, they might receive better treatment before local courts than domestic investors. ${ }^{69}$ In addition, regardless of whether a corporation would commonly be classifed as domestic, with sufficient resources it will easily side-step national law by careful corporate planning which allows them to pose as 'foreign', thus benefiting from favourable investment treaty provisions that national courts are bound to uphold. ${ }^{70}$

Wealthy investors are more likely to possess the expertise and resources to safeguard their rights, even in times of political crises that may adversely affect their investment. This is not to say that they will not suffer from time to time from the whims of capricious governments but they remain better placed and equipped to both enforce and defend their rights. Flaws in access to justice are a much more acute problem for the weakest segments of society. The UN Commission on the Legal Empowerment of the Poor has estimated that 'at least four billion people are excluded from the rule of law'. ${ }^{71}$ In its work the UN Commission documented the systemic inequalities for access to justice for the poor and vulnerable. ${ }^{72}$ Even in the most developed countries, access to courts and legal representation remains a

\footnotetext{
${ }^{66} \mathrm{E}$ Aisbett and C McAusland, 'Firm Characteristics and Influence on Government Rule-Making: Theory and Evidence' 29 European Journal of Political Economy (2013) 214, D Schneiderman (2013), 937.

${ }^{67}$ Chimni (2006), 13; E Aisbett and L Poulsen, 'Relative Treatment of Aliens: Firm-level Evidence from Developing Countries' GEG Working Paper 122, December 2016, 5.

${ }_{68}^{68}$ Aisbett and Poulsen (2016).

69 lbid.

${ }^{70}$ For example Yukos Universal Limited (Isle of Man) v. The Russian Federation and Libananco Holdings Co. Limited v. Republic of Turkey (ICSID Case No. ARB/06/8) both saw the applicants arguing that they were foreign investors because they had used corporate entities incorporated in off-shore jurisdictions to roundtrip their investments.

${ }^{71}$ UN Commission on Legal Empowerment of the Poor, Making the Law Work for Everyone Volume I, (2008)3; Report of the Secretary-General to the UNGA on Legal Empowerment of the poor and eradication of poverty (2009) A/64/133.

${ }^{72}$ UN Commission on Legal Empowerment of the Poor, Making the Law Work for Everyone Volume II Working Group Reports (2008).
} 
challenge for low income and vulnerable individuals due to lack of financial resources, inaccessibility of the law, excessive formalism, geographical distance, and lack of faith in the judiciary. ${ }^{73}$ Increasingly limited access to legal aid only serves to excacerbate this challenge. ${ }^{74}$

The inequalities prevalent in all societies disproportionately affect access to justice for the poor and vulnerable, making them suffer more than any other group from flaws in access to justice. ${ }^{75}$ In short, the evidence shows that the weakest segments of the society are in greater need of legal empowerment than international investors. It follows that policymakers concerned with legal empowerment should prioritise the needs of the former group not the latter. At the very least, within the EU and its investment treaty partner states, resources that would be allocated to the creation and maintainance of the ICS could instead be allocated to the legal needs of those who need such assistance the most.

A slightly different but equally powerful argument against the entrenchment of a justice bubble for privileged investors as proposed by the EU is that it is likely to have a fragmenting effect on local legal development ${ }^{76}$ and thus on the development process as a whole. Granted, investment can play an important role in development. However, whether the special fora for resolving investor-state disputes can make any contribution towards development goals is open to question for at least three reasons. Firstly, outsourcing IIL disputes to international tribunals without the pre-requisite of exhausting local remedies could be expected to have a chilling effect on the development of local capacity and expertise in important areas of law. ${ }^{77}$ Secondly, there is the excessive cost of international ISDS; the hugely expensive process cannot but be absorbing funds from the public purse

\footnotetext{
$73 \mathrm{~J}$ T Johnsen, Vulnerable Groups at the Legal Services Market, in Access to Justice and the Judiciary: Towards New European Standards of Affordability, Quality and Efficiency of Civil Adjudication (Intersentia 2009); A Currie, 'A national survey of the civil justice problems of low- and moderate-income Canadians: Incidence and Patterns' 13(3) International Journal of the Legal Profession (2006) 217 (Presenting examples from Norway and Canada).

74 Johnsen (2009), 33.

${ }^{75} \mathrm{M}$ R Anderson, 'Access to justice and legal process: Making legal institutions responsive to poor people in LDCs', IDS Working Paper 178, February 2003, 3.

${ }^{76} \mathrm{~T}$ Ginsburg, 'International Substitutes for Domestic Institutions: Bilateral Investment Treaties and Governance', 25(1) International Review of Law and Economics (2005) 107, 119-122.

77 Ibid, 121.
} 
that many would prefer to see allocated to improving local means for access to justice or to the progressive realisation of economic, social and cultural rights. Thirdly, IAA or ICS is likely to exacerbate inequality. Special paths of investor protection make the privileged even more privileged, thus widening the pre-existing gap that exist in domestic legal systems.

The former Special Rapporteur on Extreme Poverty and Human Rights has urged states to include the elimination of inequality in access to justice within their post-2015 development goals, viewing it as 'a vital feature of human-centred social and economic development.' 78 Public resources and the attention of policy-makers should not be dedicated to maintaining expensive paths to justice for a privileged few but to remedying the flaws and inequalities that exist at the local level. Sen has demonstrated that legal development is an integral part of the process of development, contributing to economically, politically and socially. ${ }^{79}$ Improving local access to justice, even from a utilitarian point of view, would have broader positive effects on the investment climate beyond legal protection, including the political, economic and social climate in the host states. Investor-state disputes are only one of the many types of disputes that an investor would have whilst operating in the host state. A well-functioning local legal system would benefit the investor in all its relationships with other parties, including other businesses and its employees.

Improving the local rule of law as a constituent element of, and a catalyst for, development has been on the agenda of inter-governmental organisations, national development agencies, and development banks for decades, particularly for developing countries and countries in transition. The intention, though, is not to re-state the obvious. The message here is that, regardless of the development level of a country, improving access to justice for all segments of the society would lead to more meaningful development outcomes than providing special justice paths to a privileged few.

\footnotetext{
78 M Sepúlveda, 'Equality and access to justice in the post-2015 development agenda', 2013, available at http://www.ohchr.org/Documents/Issues/Poverty/LivingPoverty/AccessJusticePost2015.pdf (last visited 10 February 2018).

${ }^{79}$ A Sen, 'What is the role of legal and judicial reform in the development process?' Paper presented at the World Bank Legal Conference on the Role of Legal and Judicial Reform in Development, 5 June 2000), 13-14.
} 


\section{E. Conclusion}

The EU's insistence on including an adapted form of IIA in its investment relationships with the US and Canada, despite lack of evidence to suggest that any of these countries fail to grant effective legal protection to investors, shows that the prioritisation of interests is not necessarily between developing and developed states, but rather-in all states-a division between the economically powerful and the disadvantaged. Within both developing and developed states, the interests of powerful business interests, local or foreign, take priority and are granted 'the highest possible protection'.$^{80}$ While IIA may empower investors from developed countries to challenge certain developing state policies, in the same way they empower investors to challenge the policies of developed states that go against their agenda.

In this essay, I have demonstrated that within states at all levels of development, investors might suffer from a weak rule of law, but that disadvantaged groups are much more seriously and disproportionately affected by such flaws. While investors may suffer from arbitrary government interference with their investments, they are better placed to fight back than the disadvantaged. Outsourcing resolution of investment disputes to specialised tribunals outside the domestic systems creates a justice bubble for powerful actors who already have significant capacity to effect change in host states. The goal here is not to advocate a complete rejection of arbitration for resolving investment disputes. As with all other types of voluntary alternative dispute settlement, investment arbitration should be available if the parties agree to submit disputes to arbitration in their investment contract. However, having IIA as the default and permanent setting is objectionable. The EU's ICS proposal takes the ad hoc justice bubbles created by a large web of investment treaties one step further by attempting to make ISDS outsourcing permanent. It is a short-sighted plan that is likely to have detrimental effects on access to justice for all.

\footnotetext{
${ }^{80} \mathrm{D}$ Schneiderman, Constitutionalizing Economic Globalization: Investment Rules and Democracy's Promise, (Cambridge UP 2008), 4.
} 